\title{
Uscio e Bottega: An Exploratory Study on Conflict Management and Negotiation During Family Business Succession in Tuscany
}

Peer-reviewed version forthcoming in World Review of Entrepreneurship, Management and Sustainable Development

\author{
Andrea Caputo \\ Lincoln International Business School, \\ University of Lincoln, UK \\ Vincenzo Zarone \\ Department of Economics and Management, \\ University of Pisa, IT
}

\begin{abstract}
This paper aims to explore how conflicts are managed, also through negotiations, during the succession phase in family businesses. The paper adopts a qualitative methodology and develops case studies of two companies, based on the interviews of the family business members belonging to multiple generations. The findings are interpreted with the dual concern model for the conflict management styles and the 2-class model for the prototype of negotiators. The results of the study show an evolutionary path regarding the conflict management style adopted by the incumbent generation, which is influenced by the role taken in the company and the historical moment. The favourite negotiator's prototype of the incumbent generations is the emotional one. The study, although exploratory, investigates a topic that is under researched both in terms of family business literature and conflict management literature. Moreover, the study offers an interesting and important bridge of the two bodies of literature, which could benefit from cross-fertilisation.
\end{abstract}

Keywords: conflict, family business, succession, Italy, negotiation, case study Article classification: research paper

Acknowledgments: This research received partial funding by the University of Pisa for the Research Program titled "Governance, control and risk management in Italian small-medium family enterprises" (PRA 2016, scientific coordinator Prof. Giuseppe D'Onza). The authors would like to thank the interviewees for their availability in sharing their experiences. The authors would also like to thank the journal's editor and the anonymous reviewers for their insightful comments that contributed to improve the research.

\section{Biographical notes:}

Andrea Caputo is Senior Lecturer in Strategy at the Lincoln International Business School (UK) and member of the Scientific Committee of the Fondazione Bruno Visentini (Rome, Italy). He received his $\mathrm{PhD}$ in Management from the University of Rome Tor Vergata (IT). He has also been a Visiting scholar at the University of Queensland Business School (AU), at 
The George Washington School of Business (USA), and at the University of Pisa (IT). His main research interests are related to negotiation, decision-making, entrepreneurship and strategic management. His work has been presented at many international conferences, such as the AOM, EURAM, BAM and the International Association for Conflict Management.

Vincenzo Zarone is Assistant Professor of Business Administration at the University of Pisa, Department of Economics and Management. Dr. Zarone received his PhD in Business Administration in 2011 from the University of Pisa, in Italy. His dissertation has been awarded a special mention by the Association of Former Officials of CNEL in Italy. He has been Visiting Professor at Lazarski University of Warsaw, in Poland. Vincenzo's main research expertise is related to family business, public management training and anticorruption measures, and accounting history. He has authored a number of national and international publications and his work has been presented at international conferences. 


\section{Uscio e Bottega: An Exploratory Study on Conflict Management and Negotiation During Family Business Succession in Tuscany}

\section{Introduction}

The old shops in Florence (botteghe fiorentine) used to have a peculiar structure coming from the Roman Empire's architectural tradition. On the front of the building, an arch dominated both the house entrance and the shop counter, which was directly facing the street. Customers would pre-negotiate goods from the street and enter the house/shop only to conclude the agreement. From this tradition, which goes back to Lorenzo the Magnificent and Machiavelli, comes the Florentine saying "Uscio e bottega", literally meaning "house and shop". This is widely used to characterise the typical structure of Italian family businesses, where the house and the business are located, still today, if not in the same building, next to each other.

In Italy it is estimated that there are approximately 784,000 family businesses amounting to the $85 \%$ of all registered companies, and weigh on employment about $70 \%$ (AIDAF 2016). Italian family businesses also stand for longevity; Five Italian companies rank among the top 10 oldest companies in the world, of those three are located in Tuscany (Barone Ricasoli est. 1141, Torrini est. 1369 and Marchesi Antinori est. 1385), which makes Tuscany a leader in the world for longevity of family business.

A debate exists over the precise definition of a family business, however it revolves around the kinship of family members owning and running a venture (Shepherd \& Haynie 2009; Seaman 2013; Kansikas et al. 2014). For the purpose of this research, family businesses are defined as businesses in which one or more family members have controlling ownership, are actively engaged in the management, administration and/or operations of the firm, and eventually foresee the future transition of the firm in the form of a within-family succession (Chua et al. 1999; Arcand 2012; Seaman 2013).

Family businesses offer a particular managerial environment, due to their peculiar characteristics coming from the intertwining between family and business interests. Therefore, conflicts in family businesses are quite complex, particularly at the time of successions where emotions and ambitions of family and non-family members could clash and collide. Despite the scarcity of research about conflict management and the subsequent negotiation processes within generational succession, it is clear that an effective conflict 
management is pivotal for the success of such an important phase of every family business. It is not a case that the main review of family business research described conflict in family business as an extremely important area for research (Sharma 2004). Yet, in a recent review of the investigations of succession in family business, Daspit and colleagues (2016) argued how conflicts' influence on the transition of power remains to be clearly articulated. Thus, this paper aims at responding to the call for research to deepen our understanding of the dynamics of conflict management and negotiation within family firms, focusing on the succession phase. Therefore, what is the style of conflict management and negotiation of small family businesses in Tuscany? How does the style co-evolve across generations? The present paper intends to investigate the characteristics of managing conflict and negotiating across different generations in family businesses and it evolved across generations. Adopting a qualitative approach, the paper analyses the case studies of two highly successful, both in terms of financial performance and in terms of management of the succession, family businesses in Tuscany. The case studies are built through semi-structured interviews. Data was analysed adopting two frameworks from the conflict management and negotiation literature: the dual concern model (Walton \& McKersie 1965; Lewicki et al. 2014; Rubin et al. 1994) and the 2-class model (Ogliastri \& Quintanilla 2016).

This study contributes to both the family business and the conflict management and negotiation literatures. It contributes to the family business literature by investigating the dynamics of conflict management and negotiation across different generations in the moment of the succession, a topic that is under-researched in literature. It also contributes to the conflict management and negotiation literature by investigating an environment that is often left behind in the field. Moreover, this study contributes to the practice of family business by proposing best practices to handle successions and conflicts derived by highly successful small family businesses, included in a traditional and historical environment (Velvin et al. 2016; Seaman 2013; Smith 2011).

The paper is structured as follows, first a conceptual framework presents a review of the relevant literature on the topic, then the methods are explained. Following, results are presented and discussed. Finally, conclusions and implications for future research are addressed.

\section{Theoretical background}


The peculiar architectural structure of family businesses is also reflected in their peculiarities in terms of managerial implications and governance structure, deriving from the familiar nature of the ownership (Dana \& Ramadani 2015; Sharma 2004; Welsh \& Raven 2006; Velvin et al. 2016; Seaman 2013). Among such differences compared to non-family businesses, family businesses are often prone to conflict and have a more complex set of issues to consider when managing conflict (Sorenson 1999; Kellermanns \& Eddleston 2007; Savolainen \& Kansikas 2013). Due to the intertwining between family and business interests and relationships, the level of conflict in family firms is compounded (Harvey \& Evans 1994; Seaman 2012). Even if it is proposed that not all conflict is bad for family firms, for example moderate task and process conflict can have a positive performance effect (Kellermanns \& Eddleston 2004), conflict can harm both family firm performance (Eddleston \& Kellermanns 2007) and the family relationship (Pitts 2000; Shepherd \& Haynie 2009).

Family businesses are characterised by the relative stability of membership over time and the multiplicity in variety of interactions (Sharma 2004). Given these characteristics, family firms offer a natural setting to understand the root causes and temporal dimensions of conflict (Astrachan \& McMillan 2003; Grote 2003). In general, the effective resolution of conflict can positively impact firm performance, both in terms of financial and nonfinancial dimensions. This is particularly true in the case of conflict arising within the succession from a generation to another (Sorenson 1999). It is generally agreed that this process extends over time and needs to be carefully planned (Sharma 2004).

Family businesses are often criticised for limiting family members' participation in the decision-making process (Eddleston \& Kellermanns 2007) and for hiring decisions based on family status rather than qualifications (Kellermanns \& Eddleston 2004). Thus, conflict is often considered as a typical characteristic of family business, which harms performances (Levinson 1971). However, conflict literature has proved that not all conflict is negative. In this stream of research, scholars have argued for studies to examine the cases where conflict can benefit family business (Kellermanns \& Eddleston 2004). Indeed, to minimise the undesirable effects of conflict and maximise the benefits, this must be effectively managed through proper conflict and negotiation strategies (Jehn 1997).

\section{Conflict in Family Firms}

Conflict may be defined as an "interactive process manifested in compatibility, disagreement or dissonance within or between social entities (i.e., individuals, group, organisation, etc.), which create organisational change" (Rahim 2002, p.207) and it is characterised by the 
"awareness on the part of the parties involved of discrepancies, incompatible wishes, or irreconcilable desires" (Jehn \& Mannix 2001, p.238).

Conflict has been classified in different ways. The prevalent classification used in management literature is based on conflict characteristics, Jehn and her colleagues (Jehn et al. 2008) differentiate between task, relationship and process conflict. In this respect, task conflict arises from disagreements concerning how a task should be performed (Jehn 1995), while relationship conflict relates to incompatibilities and disagreements about personal issues, not related to the task (Jehn 1997). Finally, process conflict involves logistical, operational and delegation issues creating disagreement on the process of accomplishing a task (Jehn, 1997).

A significant portion of the literature, as well as practical evidence, has highlighted the ways in which conflict arises among family firm members (Dyer 2006). Conflict may erupt as a result of business issues such as disagreements over growth targets, succession, product offerings, as well as from seemingly routine issues like hours of operation. At the same time, conflict may also erupt as a result of family issues such as work-life time balance, emotional relationships, family status, marital differences, family traditions, or inattention to important family events (Astrachan \& McMillan 2003). Whether the drivers are family or business related, the origins of conflicts in family business are often seen as the direct result of close and repeated interaction among the members of the family (Shepherd \& Haynie 2009).

One of the prominent explanations of the peculiarities of conflict in family firms are the role pressures and role salience associated with family and work (Carr \& Hmieleski 2015). The roles of family and business can be mutually reinforcing, but they can also result in conflicting role expectations (Shepherd \& Haynie 2009). Family members involved in the family business are likely to hold family and work roles at the same time, which may trigger inter-role conflict between these roles (Beehr et al. 1997). As a consequence, conflict dynamics are considered to be different in family versus nonfamily businesses. Moreover, since family business members often work with other family members they cannot leave family issues at home or business issues at work. This creates the opportunity for tensions to emerge from both domains and seamlessly contaminate each other (Kellermanns \& Eddleston, 2007; Eddleston \& Kellermanns 2007; de Vries 1994; Shepherd \& Haynie 2009). Incongruities can arise from the relationship and the conflicting goals of family harmony and workplace performance, leading to stresses that would be absent in nonfamily businesses (Kellermanns \& Eddleston 2007). 
Family members involved in the family firm are more likely to have their financial well-being, sometimes their livelihood, tied to the business (Dyer 2003), making the family role particularly salient (Carr \& Hmieleski 2015; Seaman 2012). Role expectations can be considered to be more challenging to meet in the family business context, consequently pressures emerging from the role as family business member are remarkably high (Carr \& Hmieleski 2015). For example, role pressures, and associated conflict, can arise from the engagement of a spouse in the firm (Rothausen 2009) or the sacrifices family business members might make for each other (Behson 2002). Similarly, leading, by ownership or management position, family business members may dictate family roles and business roles to other family business members. In the event of nonconformity to assigned roles, psychological strain or even financial sanctions can merge, complicating the conflict dynamics (Haynes et al. 1999). Associated to this is the possibility of favoured status, being it real or perceived, for certain family business members. Indeed, some family members can be in the situation of enjoying particular benefits from the business that are not tied to their own merit, leading to relationship conflict between those favoured and those not (de Vries 1994).

As previously noted, many scholars suggest that conflict has both functional and dysfunctional outcomes (De Dreu 2008; De Vliert et al. 1999; Jehn 1997; Nair 2008; Pruitt \& Rubin 1986).

Conflicts within organisations was considered as a breakdown in what were considered the standard mechanisms of decision-making in classical studies (March \& Simon 1958). This has led to the belief that conflict is a negative and destructive force that should be avoided at all costs. Deutsch (1973) elaborated that this negative image of the conflict situation was based on several elements. For example, conflicts are usually emotionally charged, and this can overwhelm clear thinking, an occurrence that is particularly risky within family members (Levinson 1971). In addition, misperception and biases are often formed because people view a situation according to their own perspectives, interpreting the situation in a stereotypical and biased fashion. Furthermore, individuals can become competitive and only perceive situations as "win-lose" scenarios (De Dreu et al. 2000). Consequently, when individuals become more committed to their own position, they are often less interested in productive communication, which can make issues more blurred and less defined. All of these may cause an escalation of conflict, since differences are magnified and similarities are neglected (Deutsch 1973).

Within family businesses, conflict between business and family can lead to both physical and psychological strain, either generating work tensions or affecting the ability to 
develop and grow the family business (Carr \& Hmieleski 2015). Indeed, there is a growing offer of counselling services catering to family businesses to deal with work and family conflict associated with the family involvement in the business (Cole \& Johnson 2012). The physical and psychological strain of family business members is mostly due to the pressures associated with their need to maintain both business processes and healthy family relationships (Werbel \& Danes 2010).

In terms of type of conflict, the imbalance of work and family relationship can surely increase the risk of moving from process or task conflict to relationship conflict. Family businesses are prone to psychodynamic effects such as rivalry among family members, children's desire to be different from their parents, marital discord, and identity conflict (Dyer 1994).

Relationship conflict was found to diminish family firm performance, as "a family firm laden with negative affect may devote insufficient attention to business needs thereby harming the family firm's performance" (Eddleston \& Kellermanns 2007).

It should be noted that conflict may have a positive effect on a family firm's performance. Conflict can be highly beneficial to a firm's performance by increasing options, by preventing premature consensus, and by increasing involvement and motivation of family firm members (Kellermanns \& Eddleston 2004; Lewicki et al. 2014; Tjosvold 2006). Among the few scholars advocating for the benefits of conflict for family firms, Cosier and Harvey (1998) have proposed that process and task conflicts could be beneficial fostering creativity and innovation.

For example, extensive research showed moderate levels of task conflict to be beneficial to the top management team's and the work group's performance in non-family business contexts (Amason \& Schweiger 1997; Jehn 1995; Jehn \& Mannix 2001). In this line, Kellermanns and Eddleston (2004) have proposed that, because of the family firms resistance to change (Sonfield \& Lussier 2004; Bresciani et al. 2013), the absence of task conflict might cause family businesses to have difficulties to adapt their strategies to turbulent environments when planning for the future.

Indeed, work-related conflict has been argued to be an effective mean for involving newest generations in the business. Similarly, addressing conflict through discussion has been considered to be more favourable than avoiding conflict for a family firm (Kaye \& McCarthy 1996). In another study, Kellermanns and Eddleston (2007) have shown how the influence of conflict on family firm performance is contingent on the psychodynamics of family involvement. Surprisingly, they found cognitive conflict to be negatively associated with 
performance, although previous research has proven the opposite relationship in other settings (e.g., Jehn 1995). A result that is explained with the peculiar characteristics of family firms which may cause conflict to escalate into animosity and personal conflicts (Kellermanns \& Eddleston 2007). It has to be noted that a clear research path investigating the benefits of conflict in family business is still missing.

\section{Generational succession, conflict management and negotiation}

Among the key events in every family business is the succession between a managing generation and the next one (Handler 1994; Dana \& Ramadani 2015; Savolainen \& Kansikas 2013). This event is often dramatic and constitutes a high risk for the survival of the firms itself; and generational succession can be amongst the main sources of conflict, impairing the decision-making process of the family business, consequently harming operations and performances (Kamei \& Dana 2012; Morris et al. 1996; Daspit et al. 2016; Miller et al. 2003). Indeed, understanding the dynamics of succession is very important as only $30 \%$ of firms survive into the second generation and only $15 \%$ survive to the third generation (Kellermanns \& Eddleston 2007).

Previous research has defined succession as "the actions and events that lead to the transition of leadership from one family member to another in family firms" (Sharma et al. 2001, p.21). Through the succession process, knowledge and roles are transferred as well as management and governance control (Handler 1994). One of the characteristics of a family firm is the desire of leaders to retain family control past their tenure (Astrachan \& McMillan 2003; Handler 1994; Smith 2011).

For example, Sharma and colleagues (2003) studied of 118 family firm leaders and revealed that the presence of a trusted successor willing to take over the leadership of a firm was pivotal to the succession planning process; suggesting the importance of engaging the next-generation family members in the planning of the succession. Within the process of succession, Dyck and colleagues (2002) suggested the importance of the appropriateness of successors' skills and experiences, timing, details by which succession will be achieved, and communication between the predecessor and successor. Miller and colleagues (2003), studying 16 failed successions, showed how the misalignment between the organisational past and future was at the heart of the failure.

Among the most recurrent themes, addressed from different perspectives of analysis, we can mention: the choice of the successor and the evaluation of its characteristics, the critical relationship between them and the predecessor, the analysis of the characteristics and 
stages in which the process unfolds generational transition (Arcand 2012). Family business entrepreneurial succession is seen as a process, articulated in several stages, which winds along a fairly long period, involving a number of roles and contemplating a series of activities, observed simultaneously or sequentially (Cabrera-Suárez et al. 2001).

With regard to this process, the literature does not offer clear indications with regard to its beginning, while you can grasp a degree of convergence in terms of its culmination, identified in the "transfer of power," namely in the transfer of control of the owner and managerial roles to the designated successor. The complexity of the dynamics that develop during the succession appears well expressed in the Handler model (1994), a slow and evolutionary process of role mutual adjustment between the predecessor and the successor. Reinventing the typical approach of the models of the enterprise life cycle, each stage of the process is associated with particular role behaviours of the predecessor and the successor and the transition from one stage is driven by the transition from a role another.

In line with that approach, other models (e.g., Gersick 1997; Daspit et al. 2016) identify a series of stages, characterised by a continuous and mutual interaction between three subsystems - owned, family, company - as well as by the performance of certain tasks. The first phase coincides generally with the awareness of the problem of generational change. The beginning can be seen as a kind of "initiation" of the future entrepreneur, who is accompanied by his predecessor through the stages of integration and intergenerational coexistence, ending with the official withdrawal of the predecessor. Throughout the various stages of this process, many appear to be the possible causes of conflicts, which arise from the opposition of values, ideas, goals, knowledge, education, professional training, risk appetite, between "father and son", or between "father and sons" where aspiring heirs are more than one, sometimes belonging to different branches of the family.

It is clear that the generation is a critical factor to consider when examining the effects of conflict in family firms (Kellermanns \& Eddleston 2004). However, the generation of the family firm was not found to directly affect conflict (Sonfield \& Lussier 2004). Tagiuri and Davis (1992) found how the first generation of a family business tend to dominate the decision-making process, while Aronoff (1998) concluded that family members in subsequent-generation firms are more likely to engage in a decision-making process based on equality. However, it is not clear yet how the generation of the family firm may impact how conflict influences firm performance (Kellermanns \& Eddleston 2007).

Research has clearly shown how family climate affects how the transfer of power occurs between generations (Daspit et al. 2016). Indeed, conflict-ridden families are likely to 
experience more turbulent transfers of power, which in turn negatively affects their performances.

As conflict is a common and inevitable facet in the daily lives of people and organisations (De Dreu 2008; De Vliert et al. 1999; Jehn 1997), it is also a key variable impacting organisational performance (Jehn et al. 1999; Pelled 1996) and is connected with emotions (Nair 2008). The ability to effectively manage conflict is critical. Studies indicate that managers spend more than twenty percent of their time dealing with conflict (e.g., Pondy 1992). Conflict is often dynamic, escalating and de-escalating depending on the situation, leading to different outcomes, whose desirability is subject to an effective management of the conflict itself.

Conflict management is an understanding of conflict as a whole, its triggers, the conflict cycle, and the conflict management styles and behaviours (Ayoko \& Konrad 2012). Conflict management also involves "designing effective macro level strategies to minimise the dysfunctions of conflict and enhancing the constructive functions of conflict in order to enhance learning and effectiveness in an organization" (Rahim 2002, p.208). This definition illustrates that the main objective of conflict management is not to eliminate conflict, but to find different ways to manage it properly through controlling the dysfunctional elements of the conflict while facilitating its productive aspects. Conflict management also refers to the styles and behaviours used by either or both parties to cope with a conflict (Pruitt 1983). As a result, an individual's response to a conflict situation with different styles and strategies may limit or enable the success of dealing with the situation (Rahim 2011).

A number of frameworks for handling conflict have been suggested and constructed by previous scholars to measure the tendency of using these approaches by each party (Rahim 2002; Thomas 1992; Thomas \& Kilmann 1978; Van De Vliert et al. 1995). Hitherto, the main model used in categorizing conflict management styles as well as negotiation strategies is the dual concern model (Rubin et al. 1994). This framework differentiates the styles of handling conflict into two distinct dimensions: i) concern for self, and the outcome one can achieve; ii) and, concern for others, and the outcome they can achieve. The concept of concern for self explains the degree to which a person tries to fulfil and satisfy his or her goals. The stronger the individual's concern for self, the more likely he or she will be to pursue conflict management behaviours or negotiation strategies that focus on personal concern for outcomes; the weaker a person's concern for self, the more likely he or she will be to pursue strategies that will overlook personal interest (Lewicki et al. 1996; Rahim 2002). Concern for others explains the degree to which individuals try to satisfy the goals and needs 
of the other party. Therefore, the stronger a person's concern for others, the more likely he or she is to engage in encouraging and helping the other party to achieve his or her outcome; the weaker the concern for others, the more likely an individual is to overlook consequences related to the other party (Lewicki et al. 1996; Rahim 2002).

By combining these two dimensions, five different styles of handling conflict emerge: competing, accommodating, collaborating, compromising, and avoiding (Rubin et al. 1994). Similarly, the dual concern model can help negotiators to select negotiation strategies within the identified conflict management behaviours. In that case, we refer to the dual concern between the importance of the relationship and the importance of the outcome for the negotiator, and the available strategies will be: competitive, accommodating, collaborative, compromise and avoiding (Lewicki et al. 1996). Due to the similarity of the two frameworks and as we agree with the view of negotiation as a way of managing conflict (Lewicki et al. 2014), for the purpose of this paper, we will refer to them indiscriminately.

Negotiation is commonly defined as a process through which two or more parties reach a needed joint decision, while having different interests and preferences (Lax \& Sebenius 1986; Raiffa et al. 2002). Due to the interdependence that takes place in multi-actor decision processes (Lewicki et al. 2014), negotiations processes and outcomes are affected by all decisions made by all the parties involved, which bring along their individual differences, attitudes, prejudices and assumptions (Chan \& Ng 2016). Negotiations are different from other group decision making processes because parties are driven by both the motivation to achieve their own interests and, at the same time, by a "we-rationality" needed to cooperate with the other party to reach a joint decision (Traavik 2011). The process is blended with dilemmas (Haber et al. 2008), and the parties involved consistently misinterpret the situation or the counterparts' interests (Caputo 2013). A brief description of the five styles can help to support our reasoning.

The competition style also called dominating or contending, involves high concern for self and low concern for others. The situation will be then characterised by each party trying to pursue its own interests (Lewicki et al. 2014). This style follows a win-lose approach where high levels of competition are found. There is no cooperation between parties, and the main aim is to win at any cost to satisfy personal concern, regardless of the concerns of others. Individuals who follow this approach try to persuade the other party to yield.

Accommodating, also called yielding or obliging, refers to "giving in to the opponent" (Euwema et al. 2003) and occurs when there is low concern for self and high concern for others. Collaborating, also referred as a problem-solving process, takes place 
when there is an attempt to integrate the interests of the parties involved to reach a joint solution (Lewicki et al. 2014). Individuals who pursue this style show high concern for self and high concern for others. As a result, cooperation and collaboration is needed to reach acceptable solutions that will satisfy both parties, otherwise known as a "win-win" or creating value approach (Lax \& Sebenius 1986). Compromising represents a moderate effort in pursuing one's personal interests and a moderate effort in helping the other party achieve his or her outcomes, therefore it refers to "settling through mutual concessions" (Euwema et al. 2003). That is, both parties give up something in order to obtain an acceptable decision. Finally, avoiding, or inaction, involves low concern for self and low concern for others, and it is characterised by avoiding confrontation on the conflict issue with the other party (Euwema et al. 2003). Some behavioural researchers suggested that the problem-solving style is the most appropriate for managing conflict (Lewicki et al. 2014). However, other researchers maintained that for conflict to be managed properly and functionally, one style may be more appropriate than another, depending on the situation (Thomas 1992).

Similar to conflict management styles, more recently Ogliastri and Quintanilla (2016), while investigating cross-cultural prototypes of negotiators, developed a framework that identifies two clusters of negotiator types: the emotional negotiator and the rational negotiator. In the first case, the emotional negotiator is characterised for the mingling of emotional factors associated with the negotiation process. There is an emphasis on the emotional aspect of the negotiation process, in which emotions play an instrumental role. For example, such type of negotiator tries to emotionally move the counterpart, expresses emotions and affection regularly, and perceives conflict as something dangerous. In the second case, the rational negotiator is characterised for the avoidance of expression of emotions or affection. There is an emphasis on the professional side of the negotiation, in which reason, neutrality and objectivity play the dominant role. For example, there is more propensity for formality of the communication exchange, punctuality and structuration of meetings, and concreteness. This model is well suited to the analysis of intergenerational conflict in family businesses, where the interplay of emotional issues, stemming from the nature of the personal relationship between family members, and issues concerning the management of the business are frequent.

To sum up, understanding the different styles of conflict management and the different prototypes of negotiators will enable individuals to select the most appropriate style when facing conflict and negotiation, by giving them the opportunity to enhance the communication process between the different parties involved. Researchers in family 
business agree that managing conflict is important to the success of the family firm (e.g., Sorenson 1999; Kellermanns \& Eddleston 2004). It has been noted how family businesses that are able to successfully manage conflict (Ibrahim et al. 2001) and those in which relationships are based on trust (Morris et al. 1997) are more likely to succeed during the succession from a generation to another; while poorly managed conflict can cause disequilibria and the demise of the family business (Harvey \& Evans 1994). In terms of conflict management styles, Sorenson (1999) adopted the dual concern model to investigate the five conflict management strategies of competition, collaboration, compromise, accommodation, and avoidance used by family firms. Collaboration, or integrative, strategies led to positive outcomes on both family and work dimensions, while avoidance and competition strategies led to poor outcomes. However, compromise and accommodation were found to be better for related to the family versus the ones related to the business.

This study aims at investigating how family members handle the conflict arising at the moment of generational succession in family businesses. Moreover, the study aims at understanding how conflict management and negotiation styles evolved depending on the moment of the succession and the generation handling the conflict. The following section presents the method used.

\section{Method}

To investigate the topic of this study the researchers sought a method that would analyse real entrepreneurs in family business, capable of capturing the dynamics of conflict management across different generations and in different times, i.e. the context and culture in which the phenomenon exists (Dana \& Dana 2005). The use of qualitative methods is considered among the most appropriate methods to investigate entrepreneurship as the creation of a case study, through interviews, surveys or observations, offers the opportunity to analyse and understand the important aspects of the environment (Dana \& Dana 2005). Moreover, the use of qualitative research in entrepreneurship has proven to develop important scientific contributions in the past decades (Dana \& Dumez 2015).

Hence, a qualitative methodology based on semi-structured interviews of several family members of two family businesses were chosen.

Family businesses were chosen for their proven capacity of effectively handling succession for multiple times in a traditional context, such the one of Tuscany. Given the exploratory nature of this research, the novelty of the field and the research objective of investigating the dynamics of conflict management and negotiation in family firms 
succession, the researchers limited the sample to two case studies, a number consistent with previous research (e.g., Harris \& Ogbonna 1999). Whilst quantitative sampling is concerned with issues of representativeness, qualitative sampling is primarily concerned with the imperative of richness of data, relegating representativeness to secondary importance. The "right" number of case studies to be investigated in scientific research is topic of debate in literature, with some arguing for a number between four and 10 (e.g., Eisenhardt 1989) and others arguing for a single deep case study being the optimum form of case study research (e.g., Dyer \& Wilkins 1991). Given the dual needs for depth and coverage, it was decided that the detailed examination of two comparable companies appears to avoid the narrowness of a single case approach whilst providing suitable depth and insight. Consequently, two medium-sized family firms, which remain owned by the founder's family, located in the province of Pisa, operating businesses related to traditional manufacturing, and facing similar challenges in terms of the need for innovation and internationalisation, were selected.

The choice of two companies operating in the province of Pisa was also mandated by the pivotal importance of intergenerational succession as a primary condition to allow the familiar character of the company as well as its survival. Particularly, the family businesses in the province of Pisa are associated by similar characteristics, such as $a$ ) the ownership structure belonging to a singular family; $b$ ) the high level of involvement of family members in the business, and the related expectations from the family; $c$ ) the pluralism of family members' involvement, i.e. several family members are usually part of the top management; d) the particular growth path of the firms, where revenues grow while the manufacturing structure does not because growth strategies are mostly deployed through outsourcing; finally, e) the growing openness to internationalisation, as a results of the improved international skills of younger generations.

The researcher interviewed three family members for each family business, gaining information from direct involvement in the successions and administration of the business. The data referred to three generations: the previous, the current and the future. Both companies are comparable as have a long history, are considered to be small businesses, are fully owned by the family, the administration of the firm is in the hand of only one family member at the time, and are located in Tuscany.

A total of six hours of interviews were carried out, and interviews were carried in the headquarters of the firm. Interviews were semi-structured and in the form of a colloquial conversation to allow interviewees to be at comfort, with questions designed to gain understanding of both the conflict management style and the type of negotiation carried out 
during the succession. Examples of questions asked during the interview are: did you experience conflicting situations with the family members involved in the business? Of which kind? How do you usually handle conflict in the family business? Which are the main challenges of negotiating with your family members?.

\section{- - - PLEASE INSERT TABLE 1 ABOUT HERE - - -}

\section{- - - PLEASE INSERT TABLE 2 ABOUT HERE - - -}

\section{Coding procedure}

The research team proceeded by analysing the interviews and isolating the relevant information according to the research objectives. A series of quotes, unanimously believed to be representative of the conflict management style and negotiator prototype have been extrapolated and used to proceed to the characterisation of the theoretical framework in relation to the case studies.

To operationalise the Ogliastri \& Quintanilla model (2016), each researcher has expressed an evaluation from one to seven (Likert scales) in relation to each of the twelve of the model. This triangulation offered a composite view of the negotiating style of each interviewee and there were no significant discrepancies among the opinions of the researchers.

Similarly, to identify the various conflict management style, by adopting the dual concern model, the research team formed a panel to analyse the interviews. Through a process of interpretation of the interviews transcript and discussion among the panel, the research team has then reached agreement on associating each conflict management style to the entrepreneur. This procedure has been applied through three different levels:

- The previous generation (predecessor) in relation with the current generation in charge (incumbent): for example, the father (predecessor), no longer at the top of the company, compared to the daughter/son (incumbent) who already succeeded him;

- The incumbent, currently leading the business, in relation with the predecessor;

- The incumbent in relation with the future generation (successor): for example, the current generation that governs the company, with respect to their children.

\section{Results}


Regarding Company A, the family member who is managing the firm has been interview, the Incumbent $\mathrm{A}$. Incumbent $\mathrm{A}$ is the younger of the two generations in the company. The company was created by the predecessors, his parents, and now managed by him.

He declares "I entered (the company, ed.) in 2007 and the biggest problem was to relate with my father". The incumbent expressed a highly conflicted relationship with the predecessor at the moment of his involvement in the company. The level of such conflict was reinforced by the statement about the choice of the incumbent's educational path. He declared "he (the father, ed.) chose everything." He was faced with few choices, which were not negotiated with the father. Surprisingly, the incumbent declared that at the moment of the succession "unexpectedly the passage it was automatic." Contrary to the setting, little dialogue on the choice of their studies, the child recognises how, when it was the time of the actual succession to his father in the company, "he axed a frightening margin, I would not have ever expected that."

However, during the period prior to the actual succession of power, it emerges a critical view of the incumbent about the predecessor's approach to decision making: "he was the owner." Moreover, the incumbent appreciates the predecessor's capacity for innovation and technical expertise - "he taught me everything there is to know about the business". During the succession process, when the incumbent gradually assumed the management responsibility of the company, the relationship between them changed, evolving towards more frequent interactions, based on mutual trust - "when I do something I always asked him for advice" and "I ask him if he can come a bit earlier to ask his advice".

About the contribution of the incumbent in the intergenerational coexistence phase, it is important the awareness of a gradual trend toward the flattening by the incumbent, declaring, despite initial enthusiasm the "everyday life absorbs you", so compared to the propensity to pursue innovations in the management of the company, the incumbent ends up "flatten out". The young director shows awareness of the possible conflicts that could be induced by an attitude of total break with the previous management style at his entrance: "is not that I could come here and revolutionise those who have been working here forever." Nevertheless, the incumbent points out that it has adopted and then developed over time a decisive approach to conflict management and shareholders: "Since the beginning, I told them: things must be done like this", leaving no space for negotiations.

The following figures represent the categorisation of the results according to the dual concern model of the Company A. 


\section{- - - PLEASE INSERT FIGURE 1 ABOUT HERE - - -}

In Company B, the incumbent, father of two daughters who are board members, has the leading role in managing the company. Despite not being directly involved in the management of the company, the two daughters have both full time jobs outside the family business, the incumbent involves them in every major and strategic decision.

The decision to extend the preparatory phase of the eventual succession in managing the company, seems to derive from a specific choice of the incumbent, declaring: "since elementary school, I said to my daughters that before coming to work in the company they had to work elsewhere for ten years."

Even if this address seems peremptory, the incumbent says that he has always left ample room for discretion and choice to his daughters, "since they were five years old, they have always made their decisions." Even in decisions relating to the educational path, the father shows himself to be very flexible: "It would be important to have a chemist in the company, but I would never ask my daughters to choose chemistry." In conflicting occasions, such as for the divergences about purchasing choices that the company had to do, the father seems very condescending towards the daughters, if there are conflicts " ... as a principle, I always do what they say", also because he appreciates their insights in assessing market trends.

The incumbent, in outlining the relationship with the predecessor (no longer present), emphasises that his path of integration in the company has been more difficult and confrontational "I was only able to do my own thing after 2000", when the predecessor was very old. The incumbent's choices were mostly imposed by contingencies and by the will of the predecessor, "My father did not explicitly tell me what to do, but in the end was that the expectation".

In the current situation, the attitude to the incumbent in dealing with his daughters, who will eventually succeed him, is not based on formalised routines, "the meetings are unstructured", probably because there is no need to structure the dialogue in a rigid way, he declares after all, currently "there are no major conflicts (...) unlike me and my father." The following figures represent the categorisation of the results according to the dual concern model of the Company B. 
The following figure represents the comparisons of the negotiation styles of Incumbent A and Incumbent B according to the 2-class model.

\section{- - - PLEASE INSERT FIGURE 3 ABOUT HERE - - -}

\section{- - - PLEASE INSERT TABLE 3 ABOUT HERE - - -}

In the next section, results will be discussed.

\section{Discussion}

According to the operationalisation of the 2-class model (Ogliastri \& Quintanilla 2016), both the incumbent of Company A and the incumbent of Company B seem to adhere more to the emotional negotiators, with higher values on the emotional dynamics of the negotiation process. For Company A, interestingly, the generation in charge, also the youngest in the company, have aptitude for formalisation of contractual relationships and the identification of more defined responsibilities for each employee, being a family member or not, in the company, which seems closer to a dominating decision-making style. This results seems to be in contradiction to previous research, which posed that subsequent generations have a tendency to adhere to decision-making styles less dominant and more equal (Aronoff 1998). The attitude toward a less emotional negotiation has clashed with the needs of "pragmatism" and the need to take decisions quickly and without creating a perception of change in established routines, which could irritate the organisational context, beyond the relationship between family members.

By analysing the dual concern model (Figure 1, Rubin et al. 1994) it can be evidenced that the predecessor's style when negotiating with the incumbent evolved from competing, in the period prior to entry of his successor in the company, to accommodating, since the incumbent took the roles of responsibility in the family business. Indeed, contrary to previous research (Tagiuri \& Davis 1992), the predecessor left blank paper to the incumbent once the power was transferred. In Company B, a similar but more linear path emerged. The incumbent had a conflicting relationship with the predecessor, who disapproved of his educational choices and expected a pre-planned path for him, although not explicitly. This constitutes an avoiding style of the incumbent and a competing style for the predecessor. 
Even during the intergenerational coexistence, and differently from Company A, the incumbent was avoiding any conflict with the predecessor, and the predecessor had a dominant decision-making style, a result closer to previous research (Tagiuri \& Davis 1992; Aronoff 1998). This attitude has affected for a long time the inclusion of Incumbent B in positions of responsibility in the company; he adopted a "wait and see" attitude until the predecessor was forced by physical issues to leave the company.

An evolutionary path emerges also in the conflict management style of the incumbent. The incumbent of Company A moved from an avoiding style of dealing with the conflict with the predecessor, which adopted a competing style at that time, to an integrative style at the stage of maturity, once he assumed the control of the company. However, the statements of Incumbent A show a constant need for comparison with his father, confirming previous evidence of the youngest generations wanting to differentiate themselves from the managing style of their predecessors (Aronoff 1998). This is also shown in regards of the incumbent relationship with his successors, as he has a strong attitude to accommodate his children, not imposing any choice for their growth and life, opposite to what he had experienced in young age. On the possible future inclusion of their children in business reality, in fact, the incumbent declares that he envisions a path of development that go along with their attitudes, since pre-school age, being this more important than the involvement in the family business.

Similarly, Incumbent B has an accommodating style with his successors, which can be explained as a reaction to his relationship with the predecessor. As for Company A, also Incumbent B encourages professional growth outside the borders of the company and does not aim to impose any choice to his successors. Moreover, about the possible future inclusion of the daughters, Incumbent B proves to have at heart the preservation of corporate balance and business continuity more than the preservation of the familiar character of the company. It is worth to note how the change in conflict management style is associated to the different role one is playing in the family business (Carr \& Hmieleski 2015), confirming an evolution of the role as a family member and as a business owner. This result is also consistent with the research in conflict management and negotiation, which has extensively proved how individuals negotiate differently according to the role they have (e.g., Appelt \& Higgins 2010; Bottom \& Studt 1993; Gelfand et al. 2002; Thompson \& Loewenstein 1992).

\section{Conclusion}

In this research the authors have explored the dynamics of conflict management and negotiation during the phases of succession within family businesses. This was done by 
developing two qualitative case studies based on direct interviews with the family business members of two companies located in Tuscany, Italy.

As noted in previous literature, the findings of this study showed that nature, frequency and intensity of conflict changes according to the phase of the succession, the business environment and the historical context in which they occur. In the preparation stage, the issues of conflict between generations often are inherent to the educational path to be taken by the prospective successor. In the analysed cases, through explicit (Company A) and indirect (Company B) pressures the predecessors influenced or determined the career choices of the incumbents, triggering a conflicting relationship. However, during the intergenerational coexistence, while Company A evolved from an avoiding (incumbent) and competing (predecessor) relationship to a collaborating style, Company B evolved only once the transition was completed. In Company A, the transition was smoother as the predecessor is still involved in corporate decisions on the request of the incumbent, which recognises the key role the previous generation had. Such events, would probably not be possible if the conflict management style had not evolved to an integrative one.

An element of analogy between the two cases comes from the analysis of the prototypes of negotiator that emerge from the interviews. Indeed, both cases are characterised to be emotional negotiators. We could speculate that this element might have triggered a more conflicting relationship in young age but helped to evolve toward a collaborating style with the previous generation and an accommodating style with the next generation. This character might derive from the cultural environment in Tuscany and the influenced structural properties of the family business. The uscio e bottega style of managing the business and the conflicts reflects the inseparable intertwining of family and business, typical of the "Made in Tuscany" tradition.

The emergence of the emotional negotiator prototype, and the consequently unpredictable impacts on the business, drive the necessity to re-affirm the importance of adequate planning for the succession (Sharma, 2004), which should be done by bearing in consideration the characteristics of the firm (size, structure, management composition, family members involved, etc.) and by formalising clear rules to promote long-term survival and prosperity (Ip \& Jacobs 2006).

The emotionality factor is also related to another important element the research found, which is the evolutionary pattern that seems to emerge, from both cases, during the transition that make the incumbent differentiate from the previous generation with respect to 
the successors, adopting an accommodating style. Despite this evolution, Company B reported a common situation in family firms, which is the delayed involvement of incumbents in the family. Whilst such delay is justified by the need to acquire experience and competence outside the family business to be later brought inside and contribute to the evolution of the family firm, the delay could also represent a critical element for the future. Indeed, studies found family harmony to be higher when the family is involved in the decision making process and when successors enter the business between 17-28 years of age (Hacker \& Dowling 2012).

These findings, of exploratory nature, might be linked to the peculiarities of the organisational structure and the limited size of the analysed companies, in which, even in managerial complexity, it is possible to envisage a less formal structure for the interactions between the actors who have to share decisions.

In terms to future research direction, it is appropriate to reiterate that, with increasing complexity of operations and or the size of the organisation, the entry of managers external to the family or even the entry of external partners into the company's ownership structure, the prototype of the negotiator should develop into the rational type, giving more attention to areas such as punctuality, the discussion of concrete facts, the prevalence of technical issues in the communication, that to date, in the case studies seem to be considered of secondary importance compared to factors related to emotional trading sphere. Moreover, the present study, as it is presenting exploratory results, calls for future efforts to deepen our understanding of the pivotal dynamics of conflict management in family business. Future studies could expand from the present results, for example by quantitatively investigating the main conflict management dynamics for family business members as well as qualitatively explaining the complex dynamics of conflict within succession. 


\section{References}

AIDAF, 2016. Le Aziende Familiari in Italia. Available at: http://www.aidaf.it/aidaf/leaziende-familiari-in-italia/ [Accessed July 22, 2016].

Amason, A.C. \& Schweiger, D.M., 1997. The Effects of Conflict on Strategic Decision Making Effectiveness and Organizational. Using conflict in organizations, p.101.

Appelt, K.C. \& Higgins, E.T., 2010. My way: How strategic preferences vary by negotiator role and regulatory focus. Journal of Experimental Social Psychology, 46(6), pp.11381142.

Arcand, S., 2012. Transmission of entrepreneurial spirit from first to second generation ethnic minorities in Montreal: Opening paths for further researches. Journal of Enterprising Communities: People and Places in the Global Economy, 6(1), pp.39-56.

Aronoff, C.E., 1998. Megatrends in family business. Family business review, 11(3), pp.181186.

Astrachan, J.H. \& McMillan, K.S., 2003. Conflict and communication in the family business, Family Enterprise Publisher.

Ayoko, O.B. \& Konrad, A.M., 2012. Leaders' transformational, conflict, and emotion management behaviors in culturally diverse workgroups. Equality, Diversity and Inclusion: An International Journal, 31(8), pp.694-724.

Beehr, T.A., Drexler, J.A. \& Faulkner, S., 1997. Working in small family businesses: Empirical comparisons to non-family businesses. Journal of Organizational Behavior, 18(3), pp.297-312.

Behson, S.J., 2002. Coping with family-to-work conflict: the role of informal work accommodations to family. Journal of occupational health psychology, 7(4), p.324.

Bottom, W.P. \& Studt, A., 1993. Framing effects and the distributive aspect of integrative bargaining. Organizational Behavior and Human Decision Processes, 56(3), p.459. Available at: http://proxygw.wrlc.org/login?url=http://search.proquest.com/docview/223183348?acco untid $=11243$.

Bresciani, S., Thrassou, A. \& Vrontis, D., 2013. Change through innovation in family businesses: evidence from an Italian sample. World Review of Entrepreneurship, Management and Sustainable Development 4, 9(2), pp.195-215.

Cabrera-Suárez, K., De Saá-Pérez, P. \& García-Almeida, D., 2001. The succession process 
from a resource-and knowledge-based view of the family firm. Family Business Review, 14(1), pp.37-46.

Caputo, A., 2013. A Literature Review of Cognitive Biases in Negotiation Processes.

International Journal of Conflict Management, 24(4), pp.274-398.

Carr, J.C. \& Hmieleski, K.M., 2015. Differences in the Outcomes of Work and Family Conflict Between Family-and Nonfamily Businesses: An Examination of Business Founders. Entrepreneurship Theory and Practice, 39(6), pp.1413-1432.

Chan, S.H. \& Ng, T.S., 2016. Ethical negotiation values of Chinese negotiators. Journal of Business Research, 69(2), pp.823-830.

Chua, J.H., Chrisman, J.J. \& Sharma, P., 1999. Defining the family business by behavior. Entrepreneurship: Theory and Practice, 23(4), p.19.

Cole, P.M. \& Johnson, K., 2012. A perfect fit: Connecting family therapy skills to family business needs. Journal of marital and family therapy, 38(s1), pp.63-71.

Cosier, R.A. \& Harvey, M., 1998. The hidden strengths in family business: Functional conflict. Family Business Review, 11(1), pp.75-79.

Dana, L.-P. \& Dumez, H., 2015. Qualitative research revisited: epistemology of a comprehensive approach. International Journal of Entrepreneurship and Small Business, 26(2), pp.154-170.

Dana, L.P. \& Dana, T.E., 2005. Expanding the scope of methodologies used in entrepreneurship research. International Journal of Entrepreneurship and Small Business, 2(1), pp.79-88.

Dana, L.P. \& Ramadani, V., 2015. Family Businesses in Transition Economies: Management, Succession and Internationalization, Springer.

Daspit, J.J. et al., 2016. Examining Family Firm Succession From a Social Exchange Perspective A Multiphase, Multistakeholder Review. Family Business Review, 29(1), pp.44-64.

Deutsch, M., 1973. The Resolution of Conflict, New Haven, CT: Yale University Press.

De Dreu, C.K.W., 2008. The Structure and Management of Conflict: Fighting or Defending the Status Quo. Group Processes \& Intergroup Relations, 11(3), pp.331-353. Available at:

http://search.ebscohost.com/login.aspx?direct=true\&db=eoah\&AN=14513854\&site=eho st-live \&scope $=$ site.

De Dreu, C.K.W., Harinck, F. \& Van Vianen, A.E.M., 2000. The Impact of Conflict Issues 
on Fixed-Pie Perceptions, Problem Solving, and Integrative Outcomes in Negotiation. Organizational Behavior and Human Decision Processes, 81(2), pp.329-358. Available at:

http://search.ebscohost.com/login.aspx?direct=true \&db=eoah\&AN=686977\&site=ehostlive \&scope $=$ site.

Dyck, B. et al., 2002. Passing the baton: The importance of sequence, timing, technique and communication in executive succession. Journal of business venturing, 17(2), pp.143162.

Dyer, W.G., 2006. Examining the "family effect" on firm performance. Family business review, 19(4), pp.253-273.

Dyer, W.G., 1994. Potential Contributions of Organizational Behavior to the Study of Family-Owned Businesses. Family Business Review, 7(2), pp.109-131.

Dyer, W.G. \& Wilkins, A.L., 1991. Better stories, not better constructs, to generate better theory: A rejoinder to Eisenhardt. Academy of management review, 16(3), pp.613-619.

Eddleston, K.A. \& Kellermanns, F.W., 2007. Destructive and productive family relationships: A stewardship theory perspective. Journal of Business Venturing, 22(4), pp.545-565.

Eisenhardt, K.M., 1989. Building Theories from Case Study Research. Academy of Management Review, 14(4), pp.532-550.

Euwema, M.C., Vliert, E. Van De \& Bakker, A.B., 2003. Substantive and Relational Effectiveness of Organizational Conflict Behavior. International Journal of Conflict Management, 14(2), pp.119-139.

Gelfand, M.J. et al., 2002. Culture and egocentric perceptions of fairness in conflict and negotiation. Journal of Applied Psychology, 87(5), pp.833-845. Available at: http://proxygw.wrlc.org/login?url=http://search.proquest.com/docview/213940018?acco untid $=11243$.

Gersick, K.E., 1997. Generation to generation: Life cycles of the family business, Harvard Business Press.

Grote, J., 2003. Conflicting generations: A new theory of family business rivalry. Family Business Review, 16(2), pp.113-124.

Haber, L. et al., 2008. Labor Negotiations, Misperceptions, and Repeated Prisoner's Dilemma: Some Extensions and Afterthoughts. Journal of Collective Negotiations, 32(3), pp.173-187. Available at: 
http://search.ebscohost.com/login.aspx?direct=true\&db=eoah\&AN=17957223\&site=eho st-live \&scope $=$ site.

Hacker, J. \& Dowling, M., 2012. Succession in family firms: how to improve family satisfaction and family harmony. International Journal of Entrepreneurship and Small Business, 15(1), pp.76-99.

Handler, W.C., 1994. Succession in family business: A review of the research. Family business review, 7(2), pp.133-157.

Harris, L.C. \& Ogbonna, E., 1999. The strategic legacy of company founders. Long Range Planning, 32(3), pp.333-343.

Harvey, M. \& Evans, R.E., 1994. Family business and multiple levels of conflict. Family Business Review, 7(4), pp.331-348.

Haynes, G.W. et al., 1999. The intermingling of business and family finances in familyowned businesses. Family Business Review, 12(3), pp.225-239.

Ibrahim, A.B., Soufani, K. \& Lam, J., 2001. A study of succession in a family firm. Family Business Review, 14(3), pp.245-258.

Ip, B. \& Jacobs, G., 2006. Business succession planning: a review of the evidence. Journal of Small Business and Enterprise Development, 13(3), pp.326-350.

Jehn, K.A., 1995. A multimethod examination of the benefits and detriments of intragroup conflict. Administrative Science Quarterly, pp.256-282.

Jehn, K.A., 1997. A qualitative analysis of conflict types and dimensions in organizational groups. Administrative Science Quarterly, pp.530-557.

Jehn, K.A. et al., 2008. The effects of conflict types, dimensions, and emergent states on group outcomes. Group Decision and Negotiation, 17(6), pp.465-495.

Jehn, K.A. \& Mannix, E.A., 2001. The dynamic nature of conflict: A longitudinal study of intragroup conflict and group performance. Academy of management journal, 44(2), pp.238-251.

Jehn, K.A., Northcraft, G.B. \& Neale, M.A., 1999. Why differences make a difference: A field study of diversity, conflict and performance in workgroups. Administrative Science Quarterly, 44(4), pp.741-763.

Kamei, K. \& Dana, L.-P., 2012. Examining the impact of new policy facilitating SME succession in Japan: From a viewpoint of risk management in family business. International Journal of Entrepreneurship and Small Business, 16(1), pp.60-70.

Kansikas, J., Huovinen, J. \& Hyrsky, K., 2014. Family firm prerequisites for international business operations: a production and marketing capabilities approach. World Review of 
Entrepreneurship, Management and Sustainable Development, 10(4), pp.435-448.

Kaye, K. \& McCarthy, C., 1996. Healthy disagreements. Family Business, Autumn, pp.7172.

Kellermanns, F.W. \& Eddleston, K.A., 2007. A family perspective on when conflict benefits family firm performance. Journal of Business Research, 60(10), pp.1048-1057.

Kellermanns, F.W. \& Eddleston, K.A., 2004. Feuding families: When conflict does a family firm good. Entrepreneurship theory and Practice, 28(3), pp.209-228.

Lax, D.A. \& Sebenius, J.K., 1986. The Manager as Negotiator: Bargaining for Cooperation and Competitive Gain, New York: Macmillan.

Levinson, H., 1971. Conflicts that plague family businesses. Harvard Business Review, 49(2), pp.90-98.

Lewicki, R.J., Hiam, A. \& Olander, K.W., 1996. Think before you speak: A complete guide to strategic negotiation, John Wiley \& Sons.

Lewicki, R.J., Saunders, D. \& Barry, B., 2014. Negotiation 7th ed., New York: McGraw Hill. March, J.G. \& Simon, H.A., 1958. Organizations, London: Wiley.

Miller, D., Steier, L. \& Le Breton-Miller, I., 2003. Lost in time: intergenerational succession, change, and failure in family business. Journal of business venturing, 18(4), pp.513531.

Morris, M.H. et al., 1997. Correlates of success in family business transitions. Journal of business venturing, 12(5), pp.385-401.

Morris, M.H., Williams, R.W. \& Nel, D., 1996. Factors influencing family business succession. International journal of entrepreneurial behavior \& research, 2(3), pp.6881.

Nair, N., 2008. Towards understanding the role of emotions in conflict: a review and future directions. International Journal of Conflict Management, 19(4), pp.359-381.

Ogliastri, E. \& Quintanilla, C., 2016. Building cross-cultural negotiation prototypes in Latin American contexts from foreign executives' perceptions. Journal of Business Research, 69(2), pp.452-458.

Pelled, L.H., 1996. Demographic diversity, conflict, and work group outcomes: An intervening process theory. Organization Science, 7(6), pp.615-631.

Pitts, G., 2000. In the blood: Battles to succeed in Canada's family businesses, Doubleday Canada.

Pondy, L.R., 1992. Reflections on organizational conflict. Journal of Organizational Behavior, 13(3), pp.257-261. 
Pruitt, D.G., 1983. Achieving Integrative Agreements. In M. H. Bazerman \& R. J. Lewicki, eds. Negotiationg in Organizations. Beverly Hills, CA: Sage.

Pruitt, D.G. \& Rubin, J.Z., 1986. Social conflict: Escalation, impasse, and resolution. Reding, MA: Addision-Wesley.

Rahim, M.A., 2011. Managing conflict in organizations, Transaction Publishers.

Rahim, M.A., 2002. Toward a theory of managing organizational conflict. International Journal of Conflict Management, 13(3), pp.206-235.

Raiffa, H., Richardson, J. \& Metcalfe, D., 2002. Negotiation Analysis: the Science and Art of Collaborative Decision Making, Cambridge (MA): The Belknap Press of Harvard University Press.

Rubin, J.Z., Pruitt, D.G. \& Kim, S.H., 1994. Social conflict: Escalation, stalemate, and settlement, McGraw-Hill Book Company.

Savolainen, S. \& Kansikas, J., 2013. Non-family employees in small family business succession: The case of psychological ownership. World Review of Entrepreneurship, Management and Sustainable Development, 9(1), pp.64-81.

Seaman, C., 2013. The invisible bedrock: business families, networks and the creation of entrepreneurial space. World Review of Entrepreneurship, Management and Sustainable Development, 9(1), pp.101-113.

Seaman, C., 2012. The invisible bedrock four constructs of family business space. World Review of Entrepreneurship, Management and Sustainable Development, 8(3), pp.297307.

Sharma, P., 2004. An overview of the field of family business studies: Current status and directions for the future. Family business review, 17(1), pp.1-36.

Sharma, P. et al., 2001. Determinants of initial satisfaction with the succession process in family firms: A conceptual model. Entrepreneurship Theory and Practice, 25(3), pp.1736.

Sharma, P., Chrisman, J.J. \& Chua, J.H., 2003. Succession planning as planned behavior: Some empirical results. Family Business Review, 16(1), pp.1-15.

Shepherd, D. \& Haynie, J.M., 2009. Family business, identity conflict, and an expedited entrepreneurial process: A process of resolving identity conflict. Entrepreneurship theory and practice, 33(6), pp.1245-1264.

Smith, R., 2011. The role of storyboards and scrapbooks in propagating entrepreneurial value in family business settings. World Review of Entrepreneurship, Management and Sustainable Development, 7(3), pp.260-271. 
Sonfield, M.C. \& Lussier, R.N., 2004. First-, second-, and third-generation family firms: a comparison. Family Business Review, 17(3), pp.189-202.

Sorenson, R.L., 1999. Conflict management strategies used by successful family businesses. Family business review, 12(4), pp.325-339.

Tagiuri, R. \& Davis, J.A., 1992. On the goals of successful family companies. Family Business Review, 5(1), pp.43-62.

Thomas, K.W., 1992. Conflict and conflict management: Reflections and update. Journal of Organizational Behavior, 13(3), pp.265-274.

Thomas, K.W. \& Kilmann, R.H., 1978. Comparison of four instruments measuring conflict behavior. Psychological Reports, 42(3c), pp.1139-1145.

Thompson, L. \& Loewenstein, G., 1992. Egocentric Interpretations of Fairness and Interpersonal Conflict. Organizational Behavior and Human Decision Processes, 51(2), pp.176-197. Available at:

http://proxygw.wrlc.org/login?url=http://search.proquest.com/docview/223189247?acco untid $=11243$.

Tjosvold, D., 2006. Defining conflict and making choices about its management: Lighting the dark side of organizational life. International Journal of Conflict Management, 17, pp.87-95.

Traavik, L.E.M., 2011. Is bigger better? Dyadic and multiparty integrative negotiations. International Journal of Conflict Management, 22(2), p.190. Available at: http://proxygw.wrlc.org/login?url=http://search.proquest.com/docview/871800291?acco untid $=11243$.

Velvin, J. et al., 2016. Social value change, embeddedness and social entrepreneurship. Journal of Enterprising Communities: People and Places in the Global Economy, 10(3).

De Vliert, E. Van et al., 1999. Constructive conflict at work. Journal of Organizational Behavior, 20(4), pp.475-491. Available at:

http://search.ebscohost.com/login.aspx?direct $=$ true $\& d b=$ eoah $\& A N=1778380 \&$ site $=$ ehos t-live \&scope $=$ site.

Van De Vliert, E., Euwema, M.C. \& Huismans, S.E., 1995. Managing conflict with a subordinate or a superior: Effectiveness of conglomerated behavior. Journal of Applied Psychology, 80(2), p.271.

de Vries, M.F.R.K., 1994. The dynamics of family controlled firms: The good and the bad news. Organizational dynamics, 21(3), pp.59-71. 
Walton, R.E. \& McKersie, R.B., 1965. A Behavioral Theory of Labor Negotiations, Beverly Hills, CA: Sage Publications.

Welsh, D.H.B. \& Raven, P., 2006. Family business in the Middle East: An eexploratory study of retail management in Kuwait and Lebanon. Family Business Review, 19, pp.2948.

Werbel, J.D. \& Danes, S.M., 2010. Work family conflict in new business ventures: The moderating effects of spousal commitment to the new business venture. Journal of Small Business Management, 48(3), pp.421-440. 
Figure 1 - Dual concern model of Company A

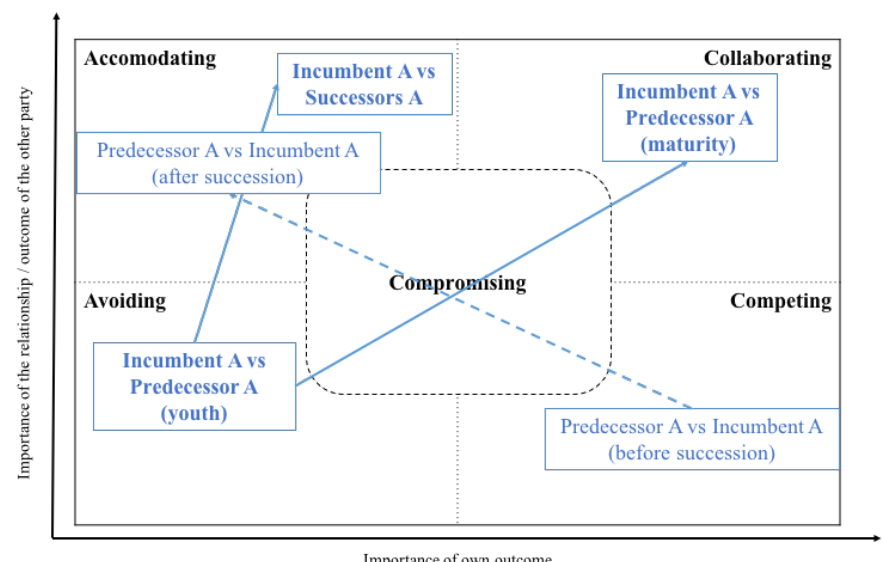

Figure 2 - Dual concern model for Company B

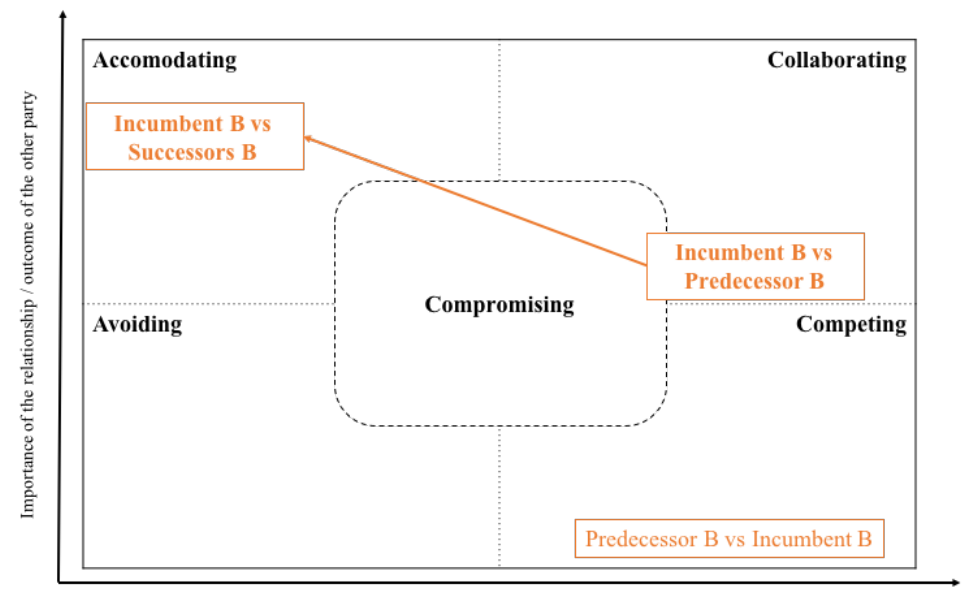

Importance of own outcome

Figure 3-2-class model representation of Company A and Company B

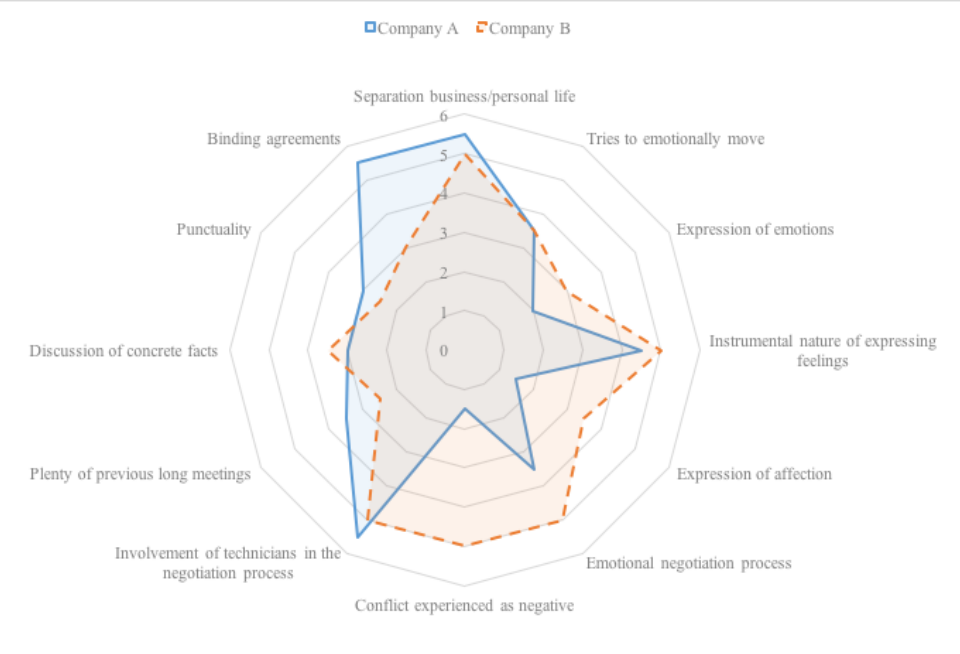


Table 1 - Description of the Companies

\begin{tabular}{lcc}
\hline & Company A & Company B \\
\hline Year of establishment & 1973 & 1805 \\
No. of generations from establishment & 2 & 6 \\
No. of employees & 11 & 14 \\
Sales (millions of euros - 2015) & 7,029 & 4,692 \\
Industry & Fashion clothes & Manufacturing \\
Year of succession & 2012 & 2000 \\
\hline \hline
\end{tabular}

Table 2 - Demography of interviewees in case studies

\begin{tabular}{|c|c|c|c|c|c|c|}
\hline Firm & Interviewees & Age range & Gender & Company role & $\begin{array}{l}\text { Family } \\
\text { Generation }\end{array}$ & $\begin{array}{l}\text { Hours of } \\
\text { interview }\end{array}$ \\
\hline \multirow[t]{3}{*}{ Company A } & The predecessor & $61-70$ & Male & $\begin{array}{l}\text { Shareholder and } \\
\text { supporting top } \\
\text { management in technical } \\
\text { tasking }\end{array}$ & $1 \mathrm{st}$ & 50 mins \\
\hline & The incumbent 1 & $31-40$ & Male & Shareholder and CEO & 2nd & $\begin{array}{l}2 \mathrm{hrs} 20 \\
\text { mins }\end{array}$ \\
\hline & The incumbent 2 & $21-30$ & Female & $\begin{array}{l}\text { Shareholder - not } \\
\text { involved in managerial } \\
\text { roles }\end{array}$ & $3 \mathrm{rd}$ & 20 mins \\
\hline \multirow[t]{3}{*}{ Company B } & The incumbent & $51-60$ & Male & Shareholder and CEO & $1 \mathrm{st}$ & $2 \mathrm{hrs}$ \\
\hline & The future generation 1 & $21-30$ & Female & $\begin{array}{l}\text { Shareholder and member } \\
\text { of the board of directors }\end{array}$ & 2 nd & 20 mins \\
\hline & The future generation 2 & $21-30$ & Female & $\begin{array}{l}\text { Shareholder and member } \\
\text { of the board of directors }\end{array}$ & 2nd & 20 mins \\
\hline
\end{tabular}


Table 3 - Summary of the main results from interviews

\begin{tabular}{|c|c|c|}
\hline Finding & Interview quotes Company A & Interview quotes Company B \\
\hline $\begin{array}{l}\text { Evolution of } \\
\text { negotiation } \\
\text { style }\end{array}$ & $\begin{array}{l}\text { In the period prior to entry, the incumbent reported } \\
\text { a difficult relationship with his father: } \\
\text { "he (the predecessor, ed.) chose everything". } \\
\text { The incumbent uses initially a competing } \\
\text { negotiation style: } \\
\text { "I entered (the company, ed.) in } 2007 \text { and the } \\
\text { biggest problem was to relate with my father" } \\
\text { Since the incumbent took the roles of responsibility } \\
\text { in the family business, the negotiation style } \\
\text { evolved to integrating: } \\
\text { "when I do something I always asked him for } \\
\text { advice (...), I ask him if he can come a bit earlier to } \\
\text { ask his advice." }\end{array}$ & $\begin{array}{l}\text { The incumbent had a conflicting relationship with } \\
\text { the predecessor, } \\
\text { "there are no major conflicts (in the relationship } \\
\text { with the future generations, ed.) unlike me and my } \\
\text { father" } \\
\text { The incumbent, then, adopted an avoiding style } \\
\text { during the intergenerational coexistence: } \\
\text { "My father did not explicitly tell me what to do, but } \\
\text { in the end was that the expectation" } \\
\text { "I was only able to do my own thing after 2000" } \\
\text { The incumbent, instead, adopted an } \\
\text { accommodating style with his successors: } \\
\text { "as a principle, I always do what they (the future } \\
\text { generation, ed.) say" }\end{array}$ \\
\hline $\begin{array}{l}\text { Prototypes of } \\
\text { negotiator }\end{array}$ & $\begin{array}{l}\text { The emotional approach to negotiation clashed } \\
\text { with the needs of pragmatism: } \\
\text { "is not that I (the successor, ed.) could come here } \\
\text { and revolutionise those who have been working } \\
\text { here forever"; "Since the beginning, I told them: } \\
\text { things must be done like this" }\end{array}$ & $\begin{array}{l}\text { Emotional negotiations and the lack of formal } \\
\text { routines: } \\
\text { "since they were } 5 \text { years old, they have always } \\
\text { made their decisions" (the future generation, ed.); } \\
\text { "the meetings are unstructured" }\end{array}$ \\
\hline $\begin{array}{l}\text { Preparation to } \\
\text { succession and } \\
\text { inter- } \\
\text { generational } \\
\text { coexistence }\end{array}$ & $\begin{array}{l}\text { Despite the initial competing style, the predecessor } \\
\text { and the successor reached a positive balance in } \\
\text { their relationship: } \\
\text { "unexpectedly the passage was automatic"; "he } \\
\text { axed a frightening margin, I would not have ever } \\
\text { expected that"; } \\
\text { The intergenerational coexistence is actually } \\
\text { fruitful: } \\
\text { "he was the owner (the father, ed.), he taught me } \\
\text { everything there is to know about the business" }\end{array}$ & $\begin{array}{l}\text { The successor has a respectful and permissive } \\
\text { approach to the intergenerational coexistence with } \\
\text { the future generations, that is actually in a very } \\
\text { early stage: } \\
\text { "since elementary school, I said to my daughters } \\
\text { that before coming to work in the company they } \\
\text { had to work elsewhere for ten years" } \\
\text { "It would be important to have a chemic in the } \\
\text { company, but I would never ask my daughters to } \\
\text { choose chemistry" }\end{array}$ \\
\hline
\end{tabular}

